\title{
Johannes Baader's Postwar \\ Plasto-Dio-Dada-Drama and German War Exhibitions during World War I
}

\author{
Katharina Hoins
}

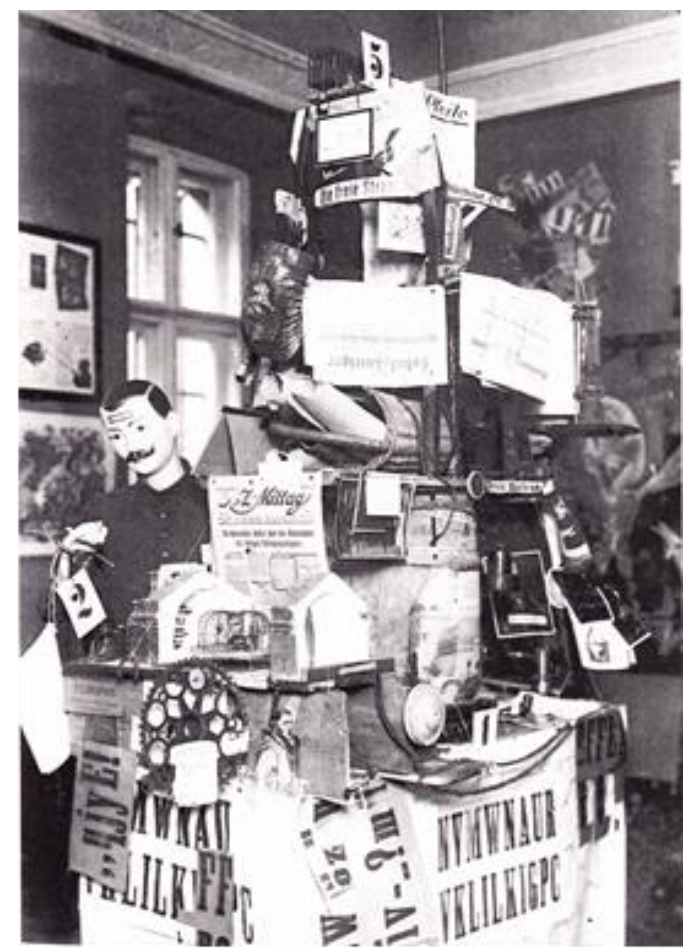

Figure 1:Johannes Baader, Plasto-Dio-DadaDrama, 1920.

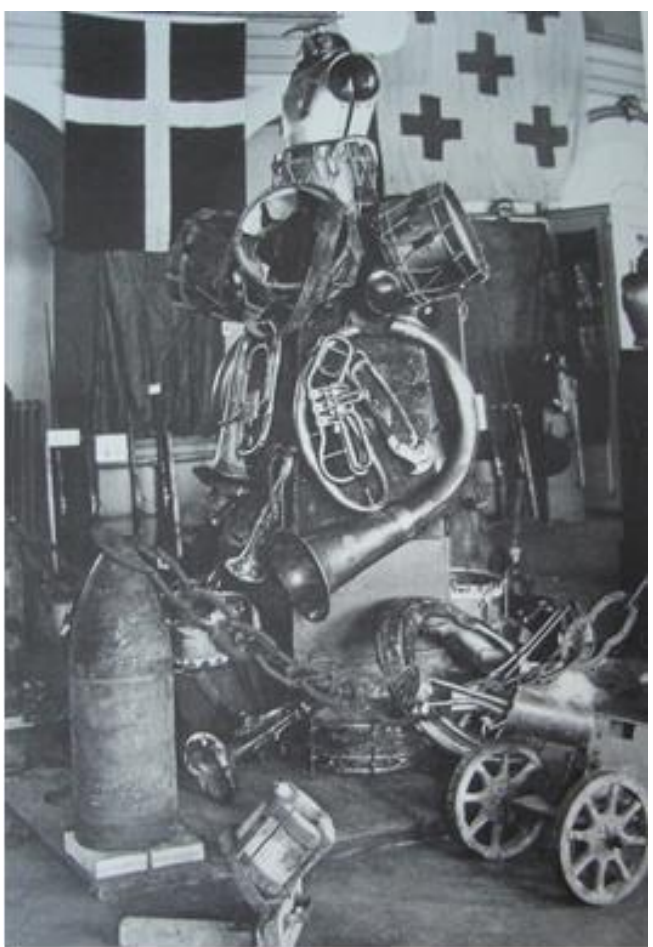

Figure 2: Trophy arrangement, German War Exhibition Freiburg, 1916.

“The World War is a newspaper war. In reality, it never existed," Johannes Baader proclaimed in 1920 in the Dada Almanach, with regard to his assemblage the PlastoDio-Dada-Drama. "So one should never believe newspapers. It's all eyewash. From the first reports of the mobilization, to Liège, the Battle of the Marne, the retreat from Russia and the armistice - the press has created the World War" (Baader, “Germany's Greatness" 101). 
In 1920, in Berlin's Galerie Burchard, Johannes Baader piled up a half-dozen different newspaper clippings and a number of other objects to form a towering "monument" (fig. 1) he called Das große Plasto-Dio-Dada-Drama: Deutschlands Größe und Untergang durch Lehrer Hagendorf oder Die phantastische Lebensgeschichte des Oberdada (The Great Plasto-Dio-Dada-Drama: Germany's Greatness and Decline at the Hands of Schoolmaster Hagendorf, or The Fantastic Life of the Superdada). In this assemblage, Baader not only dramatically exposed the press as an instrument of propaganda; he also, as this article discusses, satirized the mechanisms of popular war exhibitions, in particular their display of ephemeral press materials, such as newspapers and other periodicals. What seems at first glance a dadaist nonsense sculpture can also be interpreted as a pointed commentary on certain strategies of staging wartime propaganda. ${ }^{1}$

\section{Displaying “Deutschlands Größe und Untergang”: From War History to Current Events}

Because the Plasto-Dio-Dada-Drama was likely destroyed after the Dada Fair ended, the assemblage can only be evaluated using existing installation photographs and the complementary and contradictory notes that Baader wrote for the Dada Almanach. This existing photographic documentation and Baader's accompanying text, "Deutschlands Größe und Untergang," ultimately mediate our perception of the assemblage. The photos, some of poor quality, reveal three sides of the object. The square shape of the base implies a fourth, which was, however, not documented. Based on the photographs and the primary structure of Baader's text, in which he describes five distinct layers, the Plasto-Dio-Dada-Drama's pyramidal structure can be considered in terms of a series of levels. The base area, probably a table covered in paper with parts of Raoul Hausmann's letter poems in poster-format glued to it, forms a square. A barrel and a board rest on top of the table, with various objects and papers mounted to them. A live mousetrap, an architectural model, a toy train, and a bicycle chain and gear wheel can be seen in this second level. An edition of the Berlin daily paper B.Z. am Mittag hangs behind a tunnel-like construction. ${ }^{2}$ Baader also attached a mustachioed mannequin with dark hair to the assemblage. A chair ${ }^{3}$ provides the framework for the final upper

1 Historians also emphasize the constructed nature of World War I in its contemporary perception. See for example Krumeich 68.

2 Michael White also discusses the inclusion in this sector of a reproduction of the fifteenthcentury painting by Dirk Bouts, Christ in the House of Simon, which forms part of the collection of the Gemäldegalerie, one of the National Museums in Berlin (Preussischer Kulturbesitz). White suggests Baader references here the building of the Museum Insel and other cultural construction projects in Berlin (590).

3 Züchner erroneously describes the inclusion of metal rods (123). Such a construction would have been expensive and hardly in keeping with the ephemeral nature of the piece. 
level that displays another cluster of newspapers. The Vossische Zeitung and the Berliner Lokalanzeiger are attached next to a rusty stove pipe. Finally, Baader fastened the words "Die freie Strasse" and "Köthener Str." to the back of the chair as signposts, along with a sign bearing the inscription "spa" and a copy of the Dada journal Die Pleite (Bankruptcy).

Using newspaper clippings to confront current issues and create contemporary panoramas with collaged, juxtaposed fragments of images and text was characteristic of other Berlin Dada artists such as Raoul Hausmann and Hannah Höch. The newspapers Baader used in this assemblage are primarily from the war years and specifically record the course of battles. "Schwere Niederlage der Russen an Narew und Bug" reads the headline of the Berliner Lokalanzeiger; the front page of the Vossische Zeitung reads "Französischen Niederlage in M(...)nien". ${ }^{4}$ These headlines do not, nor are they meant to, chronicle specific, single events. Rather, they reveal the bias present in wartime news coverage and the media's specific focus on news headlines that proclaim defeats and victories. ${ }^{5}$ With his use of the B.Z. am Mittag from 20 May 1920, only a few days old at the time of the exhibition's opening, Baader incorporated up-to-the-minute events in the assemblage. In addition to these recent headlines, Baader also integrated older editions that were clearly recognizable as papers published during the war. By integrating this history, he mimicked a contemporary curatorial practice that began with the German War Exhibitions, which were initiated by the Prussian War Ministry and carried out by the Red Cross. These exhibitions of seized weapons, uniforms, and equipment, displayed alongside well-ordered rows of German military gear and uniforms in large exhibition halls as well as displays of mass media materials such as newspapers from the war, were similar to large trade or industrial fairs and could be found in nearly every major German city during wartime (Beil 161).

Baader's reference to these highly popular war exhibitions becomes particularly evident when comparing the photograph of the Plasto-Dio-DadaDrama with one of a trophy arrangement from the German War Exhibition in Freiburg (fig. 2), which took place between mid-April and mid-May of 1916 (Beil 160-78). ${ }^{6}$ Such arrangements of weaponry and gear were themselves photographed and the images were printed in catalogues that accompanied and

4 "Russians Badly Defeated at Narew and Bug," and "French Defeat in M(...)nien." The headlines cannot be made out clearly.

5 A random sampling of front pages of the Vossische Zeitung from March and April 1918 reveals that news coverage constantly focused on war events and that the headlines were dominated by defeats and victories at battles against various opponents and the numbers of prisoners taken.

6 The comparison between this particular arrangement and Baader's assemblage is not meant to suggest that Baader knew this particular one by visiting the exhibition or seeing a photograph. There were also similar arrangements in other war exhibitions. 
mediated these wartime events (Lange 33 and Deutsche Kriegsausstellung table I). By comparing the photographs we find that Baader's assemblage resembles the one in Freiburg in its pyramidal construction and the multi-storied supporting structure of cubes, rectangular boxes, and rhombuses. In spite of their geometric base, the objects in both ensembles are presented haphazardly, even chaotically. Both assemblages clearly depart from the otherwise ordered, curatorial presentation of objects on the wall or in display cases in typical historical museums and exhibitions.

There are also conspicuous similarities between the objects on display in the dadaist installation and the contemporary war exhibitions. The prominently placed signposts in Baader's assemblage, some of which are cut from dadaist magazine titles like Freie Straße, refer to the wartime practice of creating displays in the trenches. Soldiers on the front constructed small "exhibits" in these spaces, leaving gasmasks, helmets, firearms, and their own specially prepared objects as markers of their presence throughout the complex system of corridors in the battlefields (Brandt 251). The war exhibitions themselves recreated scenes of the trenches in an attempt to evoke soldiers' experiences (Beil 196-207). With mannequins as stand-ins for soldiers, these muddy recreations offered a heavy dose of the war's everyday reality to those visitors who had remained behind on the home front. There was even talk of including recordings of battle sounds in order to create the most "authentic experience" possible (Brandt 247). ${ }^{7}$ Both Baader's Plasto-Dio-Dada-Drama and the Freiburg exhibition included mannequins in their displays, the latter showing military garb by including an encased mannequin-torso dressed in armor. In his Dada Almanach text, Baader suggests the mannequin in his assemblage is a self-portrait of the Oberdada (Superdada), his alter ego. In this way, Baader ironically comments on and questions the importance and the authenticity of personal war-experience, since he had not been sent to war due to diagnosis of a depressive-maniac psychosis. Similarly, his title's allusion to dioramas ("Dio-Dada-Drama") references the war exhibition's illusionary, experiential approach (White 592), a form of three dimensional display originating in the nineteenth century.

\section{From Important Witnesses to "Dross": Newspapers in the War Exhibitions}

The inclusion of newspaper clippings in both the war exhibitions and Baader's assemblage also produced a similar sense of experience and immediacy. In his introduction to the anthology Der Weltkrieg 1914 in der Darstellung der zeitgenössischen Presse, which details how the press represented the First World War, Eberhard Buchner writes that his anthology of articles intends to "track what

7 Except where noted, all translations from German are by the translator of this article, Lance Anderson. 
is happening with immediacy, and in this way give us a history not of the war, but of our experience of the war, a history of our joy, our pride, our worries and our hopes, our errors, and our insight. The historian's pride lies in keeping his distance from the object of his research; ours should rather be that we know no distance" (7). The fact that press coverage creates a feeling of immediacy was confirmed by the journalist Hans Traub in 1928: "the newspaper gives the reader the thrill of being there - in Tokyo, in Buenos Aires, in the court room, and at the palace. In this way it strongly arouses one's imagination, and this excitement acts like an intoxicating poison, without the counterweight of solid, scientific or historical knowledge, or any sort of practical experience .... The newspaper is the medium for a basic sociological feeling of community and the need for emotional involvement" (167).

Wilhelm Pessler, a scholar in European ethnology, recommended that newspapers also be included in displays of "war collections" for similar reasons. In an essay published in 1916, which should be viewed as a standard primary text on the subject of war exhibitions, he proposes that as far as small-scale collection and exhibition projects are concerned, "an exciting image of the principle actions in the war can be obtained, on a small scale at least, when one takes the front pages of all editions of the most important newspapers from a particular city dating from a period of a quarter-year, and hangs them in the museum, perhaps temporarily, one beside another; the impact of this will verily exceed all expectations. Even if one were to display in a row the six most important newspapers from any one particular city for the duration of, for example, a week in the decisive periods of the war, the museum visitor will again recall, in the most vigorous manner, the manifoldness of events that he himself experienced" (104). As such, newspapers usually formed an integral part of the collections and presentations in war exhibitions where they offered a mediated, but seemingly direct experience of the war.

Johannes Baader's assemblage seems to respond to Pessler's suggestions in his choice of design. On the reverse side of the arrangement, Baader presented several newspapers placed in a row, a wide range of editions that formed part of the Berlin media landscape at the time. ${ }^{8}$ His selection included a tabloid, available only from street-vendors, in the form of the B.Z. am Mittag, while the Lokalanzeiger is representative of a conservative broadsheet, customarily delivered to people's homes in the greater Berlin region. The Vossische meanwhile was a respected

8 This is especially true as several other titles were included, in addition to the newspapers that cannot be identified in the photographs. Michael White concludes on the basis of the titles that Baader selected the pioneers of modern journalism for his assemblage (2001). It is my opinion, however, that the inclusion of the Vossische Zeitung as the third recognizable title and one with a long and respectable tradition is an indication that Baader was hereby aiming at presenting a broad spectrum rather than a particular type of newspaper. 
national, liberal broadsheet (see Olischewski 172-78, 142-45, 98-110). ${ }^{9}$ It cannot be said therefore that the newspapers share a common political outlook.

The newspapers, moreover, functioned as ephemera within an assemblage of other seemingly "low" materials. Neither Baader's Plasto-Dio-Dada-Drama nor typical trophy arrangements as in the Freiburg exhibition presented valuable items or objects in an impeccable state of preservation. On the contrary, they showed disfigured, damaged materials, or things isolated from their original context and function. The musical instruments and weapons captured from the enemy and placed on show in Freiburg took on a significance and value precisely through the fact that they were damaged; they served as the remnants of a battle whose traces are clearly imprinted on them. Baader also picked up on the tendency of historical "war collections" to take everyday objects and elevate them to the status of the eloquent through their importance specifically as witnesses of major events. With his gearwheel, stove pipe, and mousetrap, he parodied the meaningladen display strategies of the world war exhibitions. And by doing so, he reacted to a radical shift in how war exhibits were perceived. By the time of the Dada Fair, material that had previously been highly prized and emotionally charged in the war, as having borne witness to the momentousness of the age, had reverted to being mere matters of no consequence. ${ }^{10}$ Without the system of external references, the arrangements became assemblages of worthless items and materials. As parliamentarian Adolf Hoffmann, for example, stated in an outraged letter dated September 1919 to the local newspaper of Kaufbeuren, the war collection preserved in Berlin's military museum, the Zeughaus, was "Unrat" or mere dross (Kaiser 100).

It was precisely the systematic nature, thoroughness, and sheer number of these types of artifacts in the collections - at first highly praised - which now became a source of public criticism. As one critic wrote at the time:

[T] he zeal to collect things always likes to deport itself as the promotion of cultural history, and collecting documents of war is now generally taken to mean nothing more than the desire to illustrate, merely by amassing things that are unremarkable and random, the consequences of an epoch shaken to its very core. Indeed, the idea quickly arose to capture for posterity the memory of real events in collections that would go on public display after victory had been clinched. Gigantic plans for war

9 See the print-media database Hypress: Strukturdaten zur Berliner Tagespresse der Weimarer Republik, Österreichische Akademie der Wissenschaften, Kommission für historische Pressedokumentation $<$ https://www.oeaw.ac.at/cgi-bin/cmc/bz/frm/frm/ $>$.

10 The connection between the words Zeug (material objects) and Zeuge (witness) was made by Gottfried Korff in the context of the museum (170). In the specific context of the "world war collections" the two terms were noted by Alexandra Kaiser (100). 
exhibitions were envisaged by all. But all that is now a thing of the past! (Stockmayer 172)

After Germany's defeat, official exhibition organizers mostly abstained from holding further war exhibitions and the form vanished from public view. Baader, by contrast, now found the ideal moment to unveil his counter-monument. He exploited the shift in public opinion toward the war collections and exhibitions and erected his assemblage in June 1920, at a point when the war, now over, was perceived as a terrible legacy for the young Republic, and when hardly any energy was invested in the exhibitions (Beil 215). His parody accentuated an already perceptible trend. Whereas during the war, objects, ennobled through their silent testimony of the age, were able to stand in affirmation of a successful German war policy, the emotive impression made by similar fragments in Baader's display was of a quite different kind: they now became testaments of defeat and militarism. His indirect depictions of the exhibitions initiated by the Prussian War Ministry and implemented by the Red Cross as propaganda instruments now made an artistic contribution to the debates surrounding the concepts, commemoration, and remembrance of the First World War. Baader's anti-militarist stance in this discourse was most clearly articulated in his dramatic use of newspapers.

\section{The Word as Weapon and Archive Material: Questioning Credibility}

The creation of official German war collections and exhibits was motivated by the widespread feeling of participating in a momentous event without parallel in world history. By living through this "great age" one had a duty to document it, even while events unfolded. Suddenly, things previously deemed as unworthy of museological attention, such as objects from both the soldiers' everyday experience and the "home front," became imbued with historical significance (Griepentrog 309-11). Besides preserving objects such as weapons and uniforms, there was also a greater focus on keeping a record of printed matter such as letters, posters, and newspapers. In the words of one archivist justifying his interest in newspapers, the war was for the first time also a "war of words" whose weapons one was obliged to collect ${ }^{11}$ (Brandt 245).

Variations on the maxim "a war of words" were tossed around constantly, even while the war was being fought, perhaps most famously in 1918 by Paul von Hindenburg who, in reference to enemy propaganda in Allied airborne leaflet drops and in the press, declared: "The enemy ... not only showers our front with a barrage of artillery, but with a barrage of printed paper too" (qtd. in Didier 12). Contemporary commentators who used the weapon analogy to refer to leaflets and the press often seemed of the opinion that these means were more effective

11 For further detail on the use of collections of press clippings around 1910 for archival purposes, see te Heesen and Vogel $(33,44)$. 
than conventional instruments of war and, furthermore, could not be overcome by typical military means, as evidenced in the following statement: "he who wages war with paper and printer's ink is an enemy of a much worse and perfidious nature" (Bücher, Unsere Sache 2). In her Mitteilungen (or "bulletins") from the Weltkriegsbücherei (a World War Library based on the private collection of industrialist Richard Franck), Hermine Schützinger wrote in 1917, “ . . . whereas in simpler bygone ages the sword led the conversation, now the complicit apparatus of modern journalism wields terrible power at its position beside the cannons." 12 And in keeping with this statement, the exhibitions displayed cannons alongside newspapers, while private individuals strove not only to purchase military arms, but copies of national and regional newspapers, most preferably in complete sets with all editions from a single year, which then formed the core of their archives and exhibitions.

News media products were among the most widely collected objects not only due to their importance as weapons of war, but also because they were readily available. They formed part of the repertoire of even the most humble of collections, of which there were many after 1914, as this account, written just one year after the war by Friedrich Hilsenbeck, shows: “ . . . at first among ordinary people, nearly everyone became a collector through the mere act of carefully holding on to the daily news for safekeeping."13 The ordinary newspaper, which until then had barely survived its day, let alone year, of publication, was now transformed in great numbers into an artifact of such historical value that it was worth preserving. Many museums, libraries, and archives expanded their collections and exhibitions to include this previously unremarkable material (Brandt 244).

The collections that arose in this way had the "character of memorial and workshop in one" (Brandt 242). As contemporary statements support, the newspaper was perceived as both a primary written source and an item of realia, and was described in terms that highlighted this dual nature: "Of course newspapers from the war years, which ought to be bound, belong in libraries; they also have a sought-after place in museums, because in years to come they will not only serve as a reference work, but will be a thing worth seeing in their own right, and this applies most of all to the special editions marking important events" (Pessler 155).

The war collections, it was hoped, would serve future historians as historical sources, while simultaneously motivating the public during the ongoing war effort. Moreover, it was thought they would also serve as a memorial to the soldiers' heroic deeds and allow people to commemorate the dead. The majority

12 "Weltkriegsbücherei," in Mitteilungen von Ihrer Firma und Ihren Kollegen 5/6 (12 May 1917): 1 (qtd. in Brandt 245).

13 Die Kriegssammlung Theodor Bergmann in Fürth (Bayern) (Nuremberg: Nister, 1919) (qtd. in Lange 6). 
of archivists were confident that in contrast to all previous wars, the collection of sources written day-by-day was so seamless that this corpus of documentation, preserved almost in its entirety, would be of great benefit to future scholars and researchers (see e.g. Schulze, 20). The scale, complexity, and national importance of the events related in such archives - and in the wartime newspaper archive of the state of Hessen in particular - led Ernst Götz, archivist in the city of Darmstadt (Hessen) to speak of newspapers as "works for use in modern primary-source evaluation," which, as a modern counterpart to the Monumenta Germaniae Historica, had the potential to serve as a vast edition of primary-source material on the German-speaking world (te Heesen). This analogy also emphasizes the collections' intended commemorative character (as "Monumenta") and gives good ground for us to view the term Monumentalarchitektur or "monumental architecture" in the same light - a term that Johannes Baader (a student of architecture) chose to subtitle his assemblage.

\section{Materializing and Exhibiting Contradictions}

In his assemblage-environment, Baader completely rejected the idea that press coverage could serve as a coherent historical archive of sources. For his war collection he selected newspaper editions that gave an account of defeats of enemy troops; by doing so he highlighted a contradiction between the reports of military successes as stated by the newspapers and the actual defeat experienced by the public. Furthermore, the fact that the headlines hang toward the floor is a clear indication that the newspapers turned real events quite literally on their head. In Plasto-Dio-Dada-Drama the newspapers do not impart a sense of journalism's talent "in guiding the public through the chaos of the city" (White 590-91), but rather quite the reverse: they represent the failure of the newspapers and their inability to give meaningful direction or information. If one wishes to view Baader's monument as a memorial, then surely it is one that laments the untrustworthiness and shortsightedness of journalistic reporting.

As Baader severely questioned the credibility of language and writing, he did not merely express his argument in text-form; he constructed it, most crucially, through the very material itself. As a foundation for the (de)construction of the press's reality created during the war, in his assemblage Baader drew attention to the system of representation that is writing. The base of the construction is formed by Raoul Hausmann's sound poems "which set the tone for the erosion of its stability" (Bergius, "Merzbau" 4). The body of the tower and its upper floors were thus at risk of collapsing in on themselves at any moment. The sound poems stood for the instability that arose as a result of the shortcomings of the newspaper as a medium and the press in general. Letters and punctuation marks were arranged on large sheets of paper in a way that confounded the reader. The letters did not form words, but instead produced nonsensical, graphic formations. Capitals and lower case letters were used randomly, and punctuation marks appeared between 
letters or followed directly on from one another. Hausmann not only denied, but also sabotaged the referential character necessary for language to function. In his sound poems the signifier no longer refers to the signified, but rather to itself (Bergius, Montage 27; Benson 138).

Many dadaists voiced criticism at the fact that in the Great War the press had served as a weapon and propaganda instrument. Huelsenbeck responded to the sailors' revolt of November 1918 by posing the question, "is it a revolution of truth, a rebellion of the intellect against the war press's mountain of lies that reek to high heaven ... ?" (Huelsenbeck 51). In one of his poems he succinctly surmises: "And the lies, they weren't a problem / Ach, so faultless, the press," Huelsenbeck 62). At the time, journalists and scholars of print media were divided in opinion. Some saw the self-censorship of the press as a natural duty and their partisan involvement as a necessary precondition for a "war with printers' ink"(Bücher, Unsere Sache 38). Others were outraged at the degree of national partisanship that appeared to flout any sense of reality. In 1915, Karl Bücher (founding father of "newspaper science") wrote, "the press of all countries has, without exception, shown itself to be inadequate to the demands of the war. It has revealed an appallingly low awareness of its duty to serve the truth and the truth alone" (8-9). He vented further criticism, stating, "the papers that have been landing in our hands since the start of the war know they could report of fresh atrocities committed each day which we are suspected of having committed; reeking lies which can be uncovered as such through the simplest critical means - are being bandied around" (19).

Many German newspapers made no secret of their close collaboration with German high command and saw themselves as part of the war effort on the home front. The pacifist periodical Die Aktion, often affiliated with the Berlin dadaists, quoted a Berlin newspaper as saying, "without the self-sacrificing and unquestioning cooperation of the press, which lends its unceasing, warm-hearted support and intellectual resources to voice from day to day the united, patriotic, public opinion which keeps alive and buoys up the confidence, the trust, and the self-sacrifice [of the people], it would be impossible to conduct this war." 14 Even press organizations less inclined to cooperate with the government barely had the opportunity to deviate from the official line, because the War Press Office (Kriegspresseamt), set up in October 1915, controlled and withheld information about the war (Feldhaus 115). ${ }^{15}$ The war collections also reflected this state of affairs, something which, according to Otto Glauning in 1919, also had an impact on the newspaper clipping as a museum or archive artifact. Glauning's statement suggests the reasoning behind the Bavarian state library's abandoning of the idea of a press clippings collection lay not in a lack of suitable personnel, but partly in

14 Qtd. in Kuenzli 93. A similar opinion is expressed by Böhme (36).

15 For the practice of censorship in the First World War, see, for instance Eisermann.

http://ir.uiowa.edu/dadasur/vol21/iss1/ 
the fact that "during the war, the rigid harmonization of the news service had led to a certain homogeneity of the press."

The willing censorship and partisanship of the newspapers ultimately brought about a loss of faith in the press as a whole among many in the population, a problem the media found hard to shake off once the war had ended. In 1928 Hans Traub asked, "is there any truth in the newspaper? Can there be any truth in the newspaper? That is the key question. The pedant who used to declare 'But it said so in the paper!' is now faced with the new maxim: 'Wahrheit breitet sich nicht aus, hast die Zeitung du im Haus, '” or, 'bringing the paper home isn't a way of spreading the truth' (Traub 66). Baader can also be placed within the context of such critical voices, as he takes the awareness of the news's untrustworthiness, learned from the events of the past, and applies it in his assemblage to also include the present; he states in the Dada Almanach, "So one should never believe newspapers" (101). The B.Z. am Mittag from May 20, 1920 was no exception to this statement. Baader gave a prominent place at the center of his assemblage to this edition that had appeared just a few days before the opening of the Erste Internationale DadaMesse. ${ }^{16}$ Beneath the headline "Reich Minister Köster on the Atrocities of Colored Occupying Troops," the newspaper reported of a petition issued by the Weimar National Assembly against the deployment of black Belgian and French soldiers in the occupied territories of the Rhineland. ${ }^{17}$ The other articles featured were on "England's Declaration of War against Ireland," the "Red Armies' Offensive," the "Attack on the English on the Caspian Sea," and the effect of the Versailles Treaty on the German economy. Baader thus demonstrated that during the run-up to the opening of the 1920 Dada Fair, news reporting in Germany was once again shaped by the events of war and self-censorship. In contrast to Baader, Hans Traub, writing as a journalist, had welcomed this "regression": "In the face of the French plundering in the Ruhr, a united front in the German press presents itself once again, albeit for a short while only" (Traub 43).

The isolated text "spa" at the top of Baader's assemblage referred to the location of the July 1920 conference in Spa, Belgium, attended by the victorious allies and representatives of the Weimar government. The conference had been called to discuss the level of German repatriations and their impact on the future of Germany. Baader also had his eye on the future, for after having established that the press had created the war, he announced in the Almanach that "Superdada

16 A whole series of title pages of such different daily editions as the Rote Fahne and the Reichsbote was pasted in Baader's Handbuch des Oberdadaismus (HADO) to form a compendium of contemporary events and their coverage by the press ("Erklärung Dada"; Bergius, Lachen Dadas 165)

17 The first two paragraphs of the article appear to have been replaced by a different text and circled in dark ink. What stood in the inserted text, what purpose the intervention was supposed to serve, and the content he thereby conveyed to the viewer is no longer clear. 
will put an end to it all" (101). It would appear Baader thought that the very instrument that he had damned in his assemblage in the floors below - the press might ultimately serve as a suitable tool to overcome the prevailing state of war by bringing about social upheaval, the "Communist world revolution" (102). ${ }^{18}$ The cover of the Dada periodical Die Pleite crowned the work as part of the fifth floor that Baader entitled "World Revolution." The fact that the Berlin dadaists hoped that their own newspapers would help them get closer to the "proctatorship of the diletariat" (a satirical reversal of the "dictatorship of the proletariat") (Baader 102) is a sign that they drew quite different conclusions from the criticism directed at news journalism and the untrustworthiness of the language of journalism from those drawn by their Swiss colleagues. While Hugo Ball proposed in 1916 that "We must return to the innermost alchemy of the word . . . to keep for poetry its last and holiest refuge" (71). Baader's assemblage demonstrates that this retreat into a subjective interiority, for which the Berlin dadaists had sharply rebuked the expressionists, was not an option for them.

\section{The Ephemeral Monument as Parody of Official Memorial Culture}

Baader confronted visitors to the Dada Fair with instruments used in the enactment of war and remembrance at a point in time when official war collections and exhibitions were hardly ever on display (Kaiser 100; Beil 215). Instead, commemorative culture now focused on the erection of permanent public monuments and memorials. Fashioned mostly in stone or bronze, such monuments satisfied the material demand of being monumental in design and form (see Mittig). Baader had likewise called his 1920 assemblage a monumental sculpture. Trained as an architect, he also built mausoleums and tomb sculptures until 1905. In 1906 he envisioned an enormous utopian "Monument for Mankind," an international, interdenominational "World Temple" shaped like a pyramid (Sudhalter). In his Plasto-Dio-Dada-Drama Baader probably also consciously looked to monumental architecture designed in service to the communist revolution; he no doubt drew from the upward spiral design of Tatlin's Monument to the Third International, which Umanski had described in 1919 in an article in the periodical Der Ararat (see Züchner). Establishing a communist regime would have been, according to Baader's description in the Almanach, the last step of the evolutionary process that he visualized in the 1920 assemblage's five stories.

Another major reference for Baader's assemblage was Leipzig's Monument to the Battle of the Nations (Völkerschlachtdenkmal), completed in 1913 in the lead up to the Great War and designed to articulate the superiority of the German nation by remembering the 1813 victory over Napoleon at the Battle of Leipzig (Bergius

\footnotetext{
${ }^{18}$ Heartfield, Herzfelde, and Grosz had in fact joined the Communist Party on the day of its founding on 31 December 1918.
} 
7). On 24 February 1920, the day of the presentation of the political program of the National Socialist Party (NSDAP), Baader connected this monument directly to the rise of contemporary nationalism. From the Dada tour in Leipzig he sent a postcard of the monument to Tristan Tzara writing, "MERDE de Leipsik" (Bergius, Montage und Metamechanik 7). Baader seemed to be fascinated and inspired by the monumentality of the structure, even as he rejected its nationalistic message (Bergius 7). In his Plasto-Dio-Dada-Drama he referenced the monument, but simultaneously transformed it into parody. Crucial to this meaningful critique was the choice of unstable, "throwaway" materials for his mocking monument to the rise and fall of Germany. Baader substituted the traditional materials of memorials that imparted a sense of permanence, order, and eternity, for example stone or bronze, with ephemeral items and materials such as papers and newspapers. Newspapers in particular, printed on cheap paper, were understood as replaceable by nature; each day readers would substitute the current issue for the previous day's.

As ephemeral materials, newspapers presented a challenge to specialists in archives and museums who discussed how best to conserve, preserve, and order them. After the First World War, the impermanence of newspaper's material was used by some as legitimate grounds for scientific and scholarly institutions to retreat from the popular domain of war collections, while others complained of it as a near insurmountable problem, faced by professionals and amateur collectors alike: "The war material is too wretched for words! Light, air, dust, and humidity have destroyed the paper and print's original colors in the space of just a few short years" (Stockmayer 172). Advocates for their continued preservation were agreed; the only possibility of preserving them for the next two or three generations at the very most lay in binding together the sensitive loose sheets, if possible by month, or by year.

As the Zentralblatt für Bibliothekswesen reports, while attending the Conference of German Librarians in Weimar one month prior to the opening of the First International Dada Fair, Alfred Hilsenbeck of the Bavarian state library in Munich felt at pains to defend his position in the face of criticism thus: " . . concerning the safe-keeping and preservation of newspapers, there is little hope, we are admonishingly told; each new day devours that to which the previous gave birth, and yet it is a crime to humanity, our cultural loss, as with each newspaper destroyed we watch one of the traces of our existence vanish before our eyes" (Hilsenbeck 215). The concern now was how to make the newspapers more stable, and thus allow them to be preserved at least until the time when "the diligence of historians had sufficiently transposed them to the historiography of the nation." In concrete terms, Hilsenbeck bemoaned the fact that "in many libraries newspapers remain unbound, and are only tied up in bundles, due to the high cost of book-binding. Experience shows us that unbound newspapers rapidly disintegrate, and that only binding offers us the chance of conserving for a while longer the very poor paper used in newspaper production." 
Apart from complete editions, clippings were also collected; newspaper articles were cut out, assembled according to theme, glued onto sheets of paper, and bound in book form. Most of the news clippings collections were maintained by private individuals who later entrusted their bound volumes to public collections. It is therefore no great surprise that in addition to his newspaper assemblage - a reaction to the world war exhibitions - Johannes Baader is believed to have also produced a bound volume of newspapers. In "Erklärung Dada," Baader gives details of his newspaper collection in the following terms: "the handbook of the Superdada Oberdada is a book, fashioned by hand, of which there is but a single copy, 30/45 cm in size and $15 \mathrm{~cm}$ thick." In a circular from 1919 he states, "one imagines a book created from Berlin newspapers issued in the first half-year after the German Revolution, containing all the sheets from the Rote Fahne to the Reichs-Boten. Even the B.Z. am Mittag from 1 August 1914 is included. Newspaper upon newspaper is stored therein, minus the supplements, just the title pages with the large headings, until a thick book is formed" ${ }^{19}$ (Bergius, Lachen Dadas 154; te Heesen, Zeitungsausschnitt 195-96). Baader continued his collection at a time when some newspaper collections on the war years had long been discontinued and very few efforts had since been undertaken toward their preservation, as people avoided the memory of the initial wave of jingoism due to the humiliation of defeat. In his book he took the disillusioning war and postwar reports and juxtaposed them with the press's jubilant cries over mobilization and war fever in Berlin. Moreover, he did so in the most concrete form possible, by using the very material on which they were printed. In this way he created a personal record of the press that stood as a comment on the practices of his time analogous to his parody of world war exhibitions and collections in Plasto-DioDada-Drama.

\section{Works Cited}

Baader, Johannes. “Erklärung Dada.” Der Dada 1 (1919): n. pag. Print. . "Germany's Greatness and Decline." The Dada Almanac. Ed. Richard

Huelsenbeck. Transl. and ed. Malcolm Green. London: Atlas P, 1993. 97-102. Print.

Ball, Hugo. Flight Out of Time: A Dada Diary. Trans. Ann Raimes. Ed. John Elderfield. Berkeley: U of California P, 1996. Print. The Documents of $20^{\text {th }}$ Century Art.

Beil, Christine. Der ausgestellte Krieg: Präsentationen des Ersten Weltkriegs 19141939. Tübingen: Tübinger Vereinigung für Volkskunde, 2004. Print.

19 Te Heesen has gathered together the available sources for Baader's Handbuch des Oberdadaismus (HADO). 
Benson, Timothy O. "The Functional and the Conventional in the Dada Philosophy of Raoul Hausmann." Dada / Dimensions. Ed. Stephen C. Foster. Ann Arbor: UMI Research P, 1985. 131-63. Print.

Bergius, Hanne. Das Lachen Dadas: Die Berliner Dadaisten und ihre Aktionen. Giessen: Anabas, 1989. Print.

-. "Der Merzbau im Kontext des Architektonischen." Sprengel Museum Hannover. Text of lecture at the symposium Kurt Schwitters and the Avantgarde, 29 June-1 July 2007. Web. 26 March 2017. <http://www.sprengelmuseum.de/v1/deutsch/12schwarchiv/Bergius Der_Merzbau.pdf $>$.

- Montage und Metamechanik: Dada Berlin, Ästhetik von Polaritäten. Berlin: Mann, 2000. Print.

Böhme, Martin. Die Zeitung: Ihre Entwicklung vom Altertum bis zur Gegenwart. Hamburg: Hanseatische Verlag, 1922. Print.

Brandt, Susanne. "Kriegssammlungen im Ersten Weltkrieg: Denkmäler oder Laboratoires d'histoire?" Keiner fühlt sich hier mehr als Mensch: Erlebnis und Wirkung des Ersten Weltkriegs. Ed. Gerhard Hirschfeld, Gerd Krumeich, and Irina Renz. Essen: Klartext, 1993. 241-58. Print. Schriften der Bibliothek für Zeitgeschichte n.s. 1.

Bücher, Karl. Die deutsche Tagespresse und die Kritik. Tübingen: Mohr, 1915. Print. . Unsere Sache und die Tagespresse. Tübingen: Mohr, 1915. Print.

Buchner, Eberhard. Kriegsdokumente: Der Weltkrieg 1914 in der Darstellung der zeitgenössischen Presse. Vol. 1. Munich: Albert Langen, 1914. Print.

Deutsche Kriegsausstellung. 2 vols. Berlin: Klasing, 1916. Print.

Didier, Christophe. "Ein Trommelfeuer von bedrucktem Papier." 1914-1918 in Papiergewittern: Die Kriegssammlungen der Bibliotheken. Ed. Christophe Didier. 12-13. Paris: Somogy, 2008, Print.

Eisermann, Thilo. Pressefotografie und Informationskontrolle im 1. Weltkrieg. Hamburg: Kämpfer, 2000. Print.

Feldhaus, Erich. Das deutsche Zeitungswesen. 2nd exp. ed. Leipzig: Reclam, 1922. Print.

Glauning, Otto. “Die Kriegssammlung der Bayrischen Staatsbibliothek." Zentralblatt für Bibliothekswesen 36.7/8 (1919): 160. Print.

Griepentrog, Martin. Kulturhistorische Museen in Westfalen (1900-1950): Geschichtsbilder, Kulturströmungen, Bildungskonzepte. Paderborn: Schöningh, 1998. Print.

Hilsenbeck, Adolf. "Bibliotheken und Zeitungen." Zentralblatt für Bibliothekswesen 37.9/10 (Sept.-Oct. 1920): 214-27. Print.

Huelsenbeck, Richard. "Deutschland muß untergehen!: Erinnerungen eines alten dadaistischen Revolutionärs." 1920. En avant Dada: Die Geschichte des Dadaismus. 3rd exp. Ed. Hamburg: Nautilus, 1984. 51-62. Print.

Kaiser, Alexandra. “'Das Material zu sammeln, das dieser Krieg in solcher Fülle schuf wie keiner vorher': Kriegssammlungen und Kriegssammler im Ersten 
Weltkrieg." Aby Warburg und der Aberglaube im Ersten Weltkrieg. Ed. Gottfried Korff. 87-115. Tübingen: Tübinger Vereinigung für Volkskunde, 2007. Print. Korff, Gottfried. Museumsdinge: Deponieren - Exponieren. Ed. Martina Eberspächer. Cologne: Böhlau, 2002. Print.

Krumeich, Gerd. "Konjunkturen der Weltkriegserinnerung." Der Weltkrieg 19141918: Ereignis und Erinnerung. Ed. Rainer Rother. 68-73. Berlin: Deutsches Historisches Museum, 2004. Print.

Kuenzli, Rudolf E. "Dada gegen den Ersten Weltkrieg: Die Dadaisten in Zürich.” Sinn aus Unsinn: Dada International. Ed. Wolfgang Paulsen and Helmut G. Hermann. 87-100. Bern: Francke, 1982. Print.

Lange, Britta. Einen Krieg ausstellen: Die Deutsche Kriegsausstellung 1916 in Berlin. Berlin: Verbrecher Verlag, 2003. Print.

Mittig, Hans-Ernst. "Dauerhaftigkeit, einst Denkmalargument. " Mo(nu)mente: Formen und Funktionen ephemerer Denkmäler. Ed. Michael Diers. 11-34. Berlin: Akademie Verlag, 1993. Print.

Oschilewski, Walther G. Zeitungen in Berlin: Im Spiegel der Jahrhunderte. Berlin: Haude \& Spenersche, 1975. Print.

Pessler, Wilhelm. "Das historische Museum und der Weltkrieg." Museumskunde 12.2/3 (1916): 91-104, 155. Print.

Schultze, Walther. "Kriegssammlungen." Zentralblatt für Bibliothekswesen 35.1/2 (1918): 15-26. Print.

Stockmayer, Karl von. "Die Zukunft der deutschen Kriegssammlungen." Zentralblatt für Bibliothekswesen 37.7/8 (1920): 169-73. Print.

Sudhalter, Adrian V. "Johannes Baader and the Demise of Wilhelmine Culture: Architecture, Dada, and Social Critique 1875-1920." Diss. Institute of Fine Arts, New York University, 2005. Print.

Te Heesen, Anke. Der Zeitungsausschnitt: Ein Papierobjekt der Moderne. Frankfurt am Main: Fischer Taschenbuch, 2006. Print.

Te Heesen, Anke, and Juliane Vogel. "Herren mit Schere: Ernst Gehrcke und Karl Kraus." Papier Operationen: Der Schnitt in die Zeitung. Ed. Anke te Heesen and Jean-Baptiste Joly. 30-49. Stuttgart: merz\&solitude, 2004. Print.

Traub, Hans. Zeitungswesen und Zeitunglesen. Dessau: Dünnhaupt, 1928. Print. White, Michael. "Johannes Baader's Plasto-Dio-Dada-Drama: The Mysticism of the Mass Media." Modernism / Modernity 8.4 (Nov. 2001): 583-602. Print. https://doi.org/10.1353/mod.2001.0097

Züchner, Eva. "The First International Dada Fair in Berlin: A Meta-Mechanical Declaration of Love for Tatlin's 'Maschinenherz.'” Berlin-Moskau / MoskauBerlin 1900-1950. Ed. Irina Antonowa and Jörn Merkert. Munich: Prestel, 1995. 119-24. Print. 